\title{
Mari weddings as an object of research
}

This and the following three papers of the Communications section are based on papers presented at the meeting "Многокультурность на Поволжье. Модернизачия и идентичность марийцев, удмуртов и татаров. Семинар финно-угорской этнографии в Хельсинки 27 октября 2004 года. Modernization and the identity of Mari, Udmurts and Tatars in the multiethnic Volga-area. Meeting of Finno-Ugrian Ethnography in Helsinki on October 27, 2004.”

It was in 2002 during my first fieldwork trip to the village of Shorunzha that I hit upon Mari weddings as a research topic. ${ }^{1}$ I had gone on the trip mainly out of a sense of adventure: I wanted to see how people lived out there in remote Central Russia. I returned from the trip with what I consider a suitable subject for dissertation. Throughout my time as a student I had wanted to do academic work relating to Finno-Ugric peoples, and now it seemed possible at last. My aim in this paper will be to cast light on how I intend to investigate the research topic of my dissertation, courtship and wedding customs among the Mari.

In my research the focus will be on the experiences of a young bride and daughter-in-law, but in such a way as to take both men and women into account as necessary for courtship, for tying the marital knot and for family life. Before the wedding, the important thing is finding "the right one", i.e. a spouse, and therefore my work will also examine courtship, leisure time, going to the disco, and hanging about the streets. I have observed that few Shorunzha 20-year-olds even consider courtship - let alone getting married - seriously. A family, a spouse and children, are what they all seem to want, but the time for such things is not until later, nearer to 30 than 20 years of age. In interviews with the youth, one subject is stressed above the rest. They want to leave village and get to the city to study and work. Young people know the lifestyle of the nearby cities, Kazan and Yoshkar-Ola, and they compare that to life in the village where, as they put it, "the work is never-ending". Every household has cattle as well as a kitchen garden and land for potatoes, and the youth take part in the chores the same as the adults. There is no plumbing, so each day many buckets of water have to be carried from the well. The income of the families depends on the collective farm, or kolkhoz, and wages are paid only sporadically.

\footnotetext{
${ }^{1}$ The fieldwork project, Naisten arkea Marinmaalla (The everyday life of a Mari women), was launched at the initiative of docent Ildikó Lehtinen and assistant Helena Ruotsala. During the project (2002-2003) a group of ethnology students from Helsinki and Turku collected material in Shorunzha village for their graduate work.
} 
Since 2000 there have been on average only about a dozen weddings per year in Shorunzha, so most youth of marital age move elsewhere or remain unmarried (Shorunzha notes ${ }^{2}$ ). Shorunzha village has a surprisingly high number of young unmarried men in proportion to women their age. After completing their studies, young women remain in the city, whereas after the army young men return to the village and dream of leaving for "Siberia". ${ }^{3}$ For women, marriage would seem to be the only reason to stay in the village or to move there.

\section{Good old, bad old bread}

In the house of the bride, preparations for the ceremony have begun. There are no curtains on the windows, no rugs on the floors, for all the curtains and carpets and floors will be washed before the big day. The bride speaks calmly of her coming wedding and of the engagement party and the fiancé, who lives a full ten kilometres away in another village and is a farmer by trade.

Sergey proposed to Tania after only a few weeks of acquaintance. In something of a surprise, Sergey's family showed up at her home bringing bread, pies and vodka. Tania tells of responding to the proposal with contradictory feelings. She had discouraged Sergey from proposing as they had known each other for such a short while. On the other hand, at age 27 Tania knew that she was getting the reputation of an 'old maid'. If she did not accept the proposal now, would there ever be another opportunity? Tania was also frightened by the bread that his family brought. There is a belief that the bread of a suitor's family bears the threat of a curse: she who rejects the marriage proposal will never marry or find happiness. Surrounded by these thoughts and questions, Tania consented to the engagement, drinking as a mark of her betrothal the alcohol brought by Sergey's family. (Shorunzha notes; May 23, 2005.) ${ }^{4}$

In the Mari Republic, bread belongs to everyday life and to festivals. According to a Mari saying, bread cannot even be compared [to any other food]; bread is the most important. A bread of oat, barley and wheat flour, is made in round

\footnotetext{
${ }^{2}$ The Shorunzha administrative office keeps statistics of births and a register of marriages.

${ }^{3}$ Many Shorunzha men work in the construction, oil or gas fields of the north. These "Siberian visitors" earn many times the amount the collective is able to pay its workers. Within the village they form their own group whose standard of living is noticeably higher than that of other villagers.

${ }^{4}$ I have done fieldwork in Shorunzha village in the Mari Republic for three summers, 2002, 2003 and 2004. I study Mari wedding ceremonies and the prenuptional period, courtship and leisure time in Shorunzha.
} 
loaves for engagements, weddings, childbirths, funerals, commemorations and prayer ceremonies. In festivals, bread symbolizes well-being and happiness. (Molotova \& Sepeyev 2002: 89; Sepeyev 2001: 79-80.) In weddings, bread is exchanged between the households of the bride and groom. It is with bread and a shot of alcohol that visitors are welcomed. Bread is a subject of joy and pride, telling of a household's hospitality. But bread can also be seen à la Marcel Mauss (1999: 50) as a gift that requires reciprocity, while at the same time forging and strengthening the bonds born between families through marriage.

Bread is customarily associated with positive meanings, as is food generally. However, Tania's story of bread as the bringer of a curse shows that bread can have another side. In H. C. Andersen's fairy tale, a girl steps on some bread by accident and as a punishment sinks beneath the earth. From a very young age we are taught that bread must be treated with respect. Having bread on the table is not to be taken for granted; its absence is noticed, and remembered. Finns and Mari have both lived through times when bread, an essential everyday food, has been in short supply. In ancient Rome, grain distribution was the only existing form of public social services (Liekso 2004: 100). The bread queues of Finland during the depression told in their own bleak way of unemployment, discrimination and of an ill-being of the mind and spirit. Bread can also be used as a measure of income telling of changes in living standards over hundreds if not thousands of years. How much work have people had to do in order to buy a kilo of bread?

Bread can be a gauge for other things than the size of a moneybag. Bread can also reveal a young wife and daughter-in-law's skill - or lack thereof - at making bread. Making bread, like cooking in general, is a skill seen as passed from one generation to another. At what point has the dough risen enough? How much is enough flour? When is the oven heat right for baking? The answers to these questions are not found in cookbooks, rather, one must develop a sense for these things "in one's fingertips". (See e.g. Knuuttila 2004.) Making bread, though it may seem like a general skill not requiring much effort, is in reality the result of many years and even decades of refinement. While I was conducting an interview in a certain Shorunzha house, pancake dough was rising on the living-room table. Nadezhda, a young daughter-in-law, will in no way touch the dough bowl, add flour or even part the cloth that lies over it. Nadezhda relates that she does not participate in making bread or cooking at all. She is just beginning to learn the ways of the kitchen in her mother-in-law's house. There is a clear division of labour. Nadezhda looks after the cattle and her mother-in-law, who is known for her splendid pancakes, is responsible for preparing the food and making the bread. (Shorunzha notes; August 15, 2003.) 


\section{Disturbing the peace and quiet}

The morning of Tania and Sergey's wedding is sunny. The street before the house is peaceful. Inside the house of the bride, the mood is one of excited anticipation. While friends are helping the bride, relatives are in the kitchen preparing food and in the living room setting tables. Everything would seem to be proceeding to plan, until at exactly half past ten a car is heard honking its horn in the street. The groom's folk had arrived, and they are ahead of time, of course! The tranquil mood disappears. The bride isn't anywhere near ready. The bridal gown is slipped over Tania quickly, her friends begin to lace the cords at the back of her dress. The groom's folk begin singing and playing music as soon as they get out of the car before the bride's house. The women guests from the part of groom, the süanvate, sing in a circle while the men dance in the middle. Every so often there's a loud whistle from one of the men. The songs and dances are accompanied by harmonica and drum. (Shorunzha notes; June 5, 2004.)

There are various sounds that are an essential part of Mari wedding festivities. There is ordinary speech and laughter, but also loud noise-making that causes heads to turn and people to gather in the street. The sounds reveal that something out of the ordinary is happening. Aleksandra Fuks (Fuchs), a researcher of the Mari, focused attention on sounds in her observations of Mari weddings in the mid-1800s. Fuks relates in her travel book that Mari weddings were not at all pleasant to watch. A bridegroom's folk arrive to fetch the bride, who with creases on her brow and dressed plainly in a white embroidered shirt looked about to burst into tears at any moment. The groom's folk are loud and boisterous - there is shouting, some begin dancing, and the noise is continuous. There is eating and drinking and dancing. The music threatens to make everyone present permanently deaf, according to Fuks. There is hard clapping and heavy stamping. The rowdy noise and shouting continues up until a dowry is gotten from the shed. A fight breaks out when the bride's sister, sitting on the bridal trunk, shoves a drunken man, who flares up and strikes the girl. The groom pays out money to the sister to stop the fight. The groom's folk set out towards the groom's home village accompanied by song and playing of music. The wagons are decorated with chimes and sleigh bells. At familiar houses along the way, they stop and are offered beer. The song and music continue for the entire length of the trip. (Fuks 1840: 222-231.)

Helena Saarikoski studied the Finnish tradition of penkinpainajaiset ("putting up the benches"), when the candidates for the matriculation exams celebrate their last day in the school, and she concluded that it is the best school day (kouluajan kivoin päivä). During these event the everyday school routine is turned upside-down. It is a day when being disruptive and rowdy is permitted. 
(Saarikoski 1994: 140-142.) Similarly in Mari weddings the groom's family may disturb the peace of the bride's hometown. The bride is fetched in a way that makes all the people in her village notice. The groom's family goes up and down the village streets playing instruments and singing, making visits at many homes, and - as in the last day at school celebration tradition - the songs may be rude, suggestive, mean, and even approach personal offence. (Saarikoski 1994: 140.) In penkinpainajaiset, it is the teachers who get roasted; in Mari weddings, it is the bride.

Vasiliy's daughter, Anna, was said to have lots of silver.

If she had had lots of silver, she'd have built a silver bridge.

Vasiliy's daughter, Anna,

from the front looks like a board, from the back looks like a tangled mop,

staring at her feet like a sluggard.

But maybe for us even a sloth is enough:

the time to leave has come,

fast, get the bride to get a move on.

(Yevsev'yev. Folkloristica V. Collection of V. M. Vasil'yev, Kozhlaer village, Morki district, song 466, 1928.)

Historian Peter Englund in his article "Hiljaisuuden historiasta" ("About the history of silence') compares the different sound worlds of the city and the country in times past. Where the acoustic horizon of the country was broad, that of the city was - and is - much more constricted. In the country there is room for nature's own sounds, for the wind and the rain, bird songs and barking dogs. The sound world of the country may be disturbed by gunshots and thunder, and also by church bells, which were designed so that their sound would cover the entire parish. The low resounding of church bells carrying far and wide aroused respect, but they also transmitted important messages. They signified a call to worship, or told of sorrow or joy, or gave a warning of war or a fire alarm. It was also supposed that sounds could protect people from various dangers and frighten evil spirits away. (Englund 2004: 18-20.) In Mari weddings the groom's folk move through the bride's village noisily, and every villager hears the noise and recognises the message it conveys. A girl is moving away from her parents to another village, becoming a daughter-in-law in an unfamiliar household. It is an unusual time in many respects, and one can hypothesis that a purpose of the noise is to keep the evil spirits at bay. A feeling that evil spirits are on the move is indicated by the fact that Tania, who got married in the summer of 2004, mentioned having sought protection ahead of the wedding by 
keeping a safety pin in her lapel and her underwear turned inside-out. (Shorunzha notes; May 20, 2004.)

\section{At the disco}

I have learned that working in the field means continuous observation, especially in situations like this where one is among a community whose traditions and way of life are unfamiliar. Moving about in the field, you have to keep your senses alert all the time and try to understand what is happening around you and what is being talked about. Observation is a natural and essential part of fieldwork, but how is the material obtained through observation to be used in the research itself? According to Hanna Snellman (2003: 27), there are ethical problems related to observation, problems that the cultural researcher should be aware of when conducting research. It is wrong to monitor human research subjects if they do not know they are the objects of examination. This kind of observation-related problem became actualised for me while at a Shorunzha disco. The problem was not formed from my being in some way inobservant or not cognizant of something; on the contrary, it was rather on account of my knowledge and feelings, which were roused in me by the visit to the disco.

I wanted to acquaint myself with the disco because many of the married and unmarried couples I have met said the courtship with their future spouse began there. The disco is part of the leisure time of almost every Shorunzha youth. Disco dances are organised at the Shorunzha club, or cultural centre, three or four nights a week during the summer and on Fridays and Saturdays during the winter. Visitors to the disco are unmarried youth aged 12 to 25 . It is to be noted, however, that the "upper age limit" applies to unmarried women only; unmarried men still go to the disco in later years.

In the Shorunzha club the light is dim and the techno music is pulsating loudly. Only a few young women are dancing on the dance floor. This is not unusual, because it's only $11.00 \mathrm{pm}$. Most of the young people are still outside the club. Attention is drawn to men of various ages walking purposefully across the floor. Where are they actually going? Where do they come from?

There are figures standing at the edge of the stage. Lights are suddenly turned on the stage and one can see as far as the back of the hall that men are standing in lines, their faces turned towards the dance floor. Soon the men set themselves beside the ring of the stage and begin eating and having drinks. Young women approximately 14 to 18 years of age are dancing at the front of the stage. They are dressed in tight jeans and tummy shirts. Some of the dancers are quite provocative, giving out cries and writhing 
contortions on stage before the standing men. (Shorunzha notes; May 29, 2004.)

My first reaction in the disco was astonishment. How is it possible that young women accept being ogled at by men in such a conspicuous way, and how is it that some actually seem to enjoy it? Such direct objectification of women felt degrading and thus wrong. Furthermore it seemed to me to be unfair that men over 30 years of age could enter the disco, but passage was barred for women of the same age. After that night, I thought a lot about whether I could use the observations I had made at the disco in the research. I did not want to offend the community I was examining or present an unfavourable picture of them. But would it also be unethical to leave it unwritten? Does a researcher have an obligation to write about perceived social wrongs also, even (or especially) when they are the researcher's own interpretation of events? Billy Ehn and Barbro Klein write that the object of research considered by a cultural researcher is viewed against the researcher's own background and experience. At the same time as one is examining the "Other", one also is thinking more or less about one's own existence. (Ehn \& Klein 1994: 10.) I can apply this to the present case and think of treating the courtship of young people at the Shorunzha disco as a relevant phenomenon in a way that, without being judgmental of anyone and by giving balanced consideration to both sexes, takes also into account my own role as an influencing factor in the interpretation.

\section{The journey continues}

In this paper I have made a survey of several phenomena relating to Mari weddings and courtship, themes that I intend to investigate also in my forthcoming dissertation. Before reaching this end, there is still ahead of me the work of collecting more material, observations and interviews, and becoming more familiar with the literature and archival material. Cultural analysis is the approach selected for my research. By means of this approach, I can offer to Finnish readers as well as to Mari readers themselves a viewpoint different in comparison to, for example, that found in Mari researchers' own research.

The cultural analytic approach aims to distinguish the private from the collective, while nevertheless viewing the individual as part of his or her community of dwelling, and as part of society and ultimately the entire world. By means of "condensed" interpretation, the object of research is searched for details that may be compared and contrasted. Dramatisation is also allowed. The researcher should get beyond the surface structure of the phenomenon to the inside and see the meaningfulness of the object of investigation in its multiplicity. It is essential for the researcher and the reader to notice in a familiar, seemingly prosaic phenomenon something new and surprising. (Ehn \& Löfgren 
2001.) For example, multiple levels and meanings can be found in bread when it is considered not only as a valuable and vital food item, but also as a bringer of misfortune, a symbol of poverty, and a measure by which to appraise a daughter-in-law's cooking skills.

My research dealing with Mari marriage ceremonies is still in its early stages. Over the course of three fieldwork trips, my knowledge of Mari folk culture has increased, but there is still much to be seen and experienced. I do not strive to produce the most comprehensive presentation possible, of course; as a foreign researcher, i.e. an outsider, I do not have the necessary qualifications for that. (See Ruotsala 2002: 48-50.) ${ }^{5}$ Whereas a hundred years ago ethnologists and linguists searched for cultural connections and distant ancestral relations among Finno-Ugric peoples, nowadays one primarily finds people who speak as their mother tongue a language related to the Finno-Ugric language family and who live as a minority in a Central Russian republic bearing their name.

Ethnologic research endeavours to tell the human story from the perspective of the individual. Instead of people getting hidden behind statistics, their stories, thoughts and personal experiences are at the centre of the research. (Snellman 1997: 15; 2003: 11.) While in the field, there is continual dialogue. What the members of the community being researched have to say to the researchers is not the only matter of importance. In situations of interaction between people, the topics of conversation arise at the points where the lives of individuals - of Mari and Finnish - converge. I will not forget the time a bride whose wedding was only a few weeks away was asking me about my own wedding, at the end asking with anxiety: was it worth it, I mean, getting married?

\section{References}

\section{Unpublished sources}

Shorunzha notes $=$ Fieldwork material from Shorunzha village from 2002, 2003 and 2004. In the author's possession.

Yevsev'yev = Archives of the Finno-Ugrian Society. Timofey Yevsev'yev. Folkloristica $V$.

\section{Published sources}

Ehn, Billy \& Klein, Barbro 1994: Från erfarenhet till text: om kulturvetenskaplig reflexivitet. Stockholm.

\footnotetext{
${ }^{5}$ By the early 1990s, there was a shift in ethnology away from positivistic descriptions of truth towards a more holistic examination of the entire research process, one in which research results are affected by the researcher's persona and by the dialogue between researcher and the object of research.
} 
Ehn, Billy \& Löfgren, Orvar 2001: Kulturanalyser. Malmö.

Englund, Peter 2004: Hiljaisuuden historia. Helsinki.

Fuks (Fuchs) $=$ Фуксъ, Александра 1840: Записки Александры Фуксъ о чувашахъ и черемисахъ Казанской губерній. Казань.

Knuuttila, Maarit 2004: Keittämisen taito. - Maarit Knuuttila, Jyrki Pöysä \& Tuija Saarinen (eds.), Suulla ja kielellä - tulkintoja ruuasta. Tietolipas 202. Helsinki.

Liekso, Hanna 2004: Roomalainen ruokakulttuuri. - Marja-Leena Hänninen \& Maijastiina Kahlos (eds.), Roomalaista arkea ja juhlaa. Tietolipas 201. Helsinki.

Mauss, Marcel 1999: Lahja: vaihdannan muodot ja periaatteet arkaaisissa yhteiskunnissa. Tutkijaliiton julkaisu 94. Helsinki.

Molotova \& Sepeyev = Молотова, Т. Л. \& Сепеев, Г. А. 2002: Современная пища и утварь марийцев. - Н. Ф. Мокшин (ed.), Современная этническая культура финно-угров Поволжья и Приуралья. Йошкар-Ола.

Ruotsala, Helena 2002: Muuttuvat palkiset. Elo, työ ja ympäristö Kittilän Kyrön paliskunnan ja Kuolan Luujärven poronhoitokollektiiveissa vuosina 1930 - 1995. Kansatieteellinen arkisto 49. Helsinki.

Saarikoski, Helena 1994: Kouluajan kivoin päivä: folkloristinen tutkimus penkinpainajaisperinteestä. Suomalaisen Kirjallisuuden Seuran Toimituksia 617. Helsinki.

Sepeyev $=$ Сепеев, Г. А. 2001: Пища и утварь. - Г. А. Сепеев (ed.), Этнография марийского народа. Йошкар-Ола.

Snellman, Hanna 1997: Tukkilaisen tulo ja lähtö: kansatieteellinen tutkimus Kemijoen metsä- ja uittotöistä. Scripta historica 25. Oulu.

Snellman, Hanna 2003: Sallan suurin kylä - Göteborg. Suomalaisen Kirjallisuuden Seuran Toimituksia 927. Helsinki.

Mari Immonen <mari.immonen@helsinki.fi>

Institute for Cultural Research

Finno-Ugric ethnology

P.O. Box 59

FI-00014 University of Helsinki 